\title{
DEFICIENCIES IN THE AIR QUALITY ACT OF I967
}

\author{
JOHN E. O'FALION*
}

\section{INTRODUCTION}

In 1955, the Eighty-fourth Congress enacted Public Law 159. ${ }^{1}$ This first federal legislation dealing with air pollution control stated "that the prevention and control of air pollution at its source is the primary responsibility of states and local governments." Public Law I59 authorized the Department of Health, Education, and Welfare (HEW) to provide technical support for state and local programs, and to conduct research. This 955 federal law officially recognized the presence of a nationwide air pollution problem and provided for a study of the problem. It did not take positive steps to control air pollution.

Studies fostered by Public Law 159 revealed the imminent threat of air pollution. Meanwhile, the situation grew worse. Awareness of the inadequacy of then existing control efforts led to adoption of the Clean Air Act of $1963 .^{2}$

The Clean Air Act launched an attack on air pollution. Federal activities were greatly expanded and federal grant funds were made available to state and local air pollution control agencies for the first time. The availability of grants for air pollution control did much to stimulate abatement activity. Not all state and local control programs initiated under the Clean Air Act of 1963 were sufficiently vigorous, however; and more sophisticated understanding of the complexities of air pollution and its control demonstrated the need for further legislation at the federal level. In November of $x 967$, Senate Bill 780 , cited as the Air Quality Act of 1967 , was signed into law. ${ }^{3}$

The Department of Health, Education, and Welfare has referred to the Air Quality Act of 1967 as a blueprint for systematic effort to deal with air pollution problems on a regional basis calling for coordinated action at all levels of government and among all segments of industry.

The act provides for:

- B.S. (Civil Engineering) I937, University of Colorado; LL.B. I947, Denver University. Director of the Building Department and Director of Air Pollution Control, City and County of Denver, Colorado. Registered Professional Engineer. Member of the Colorado bar and of the Federal Bar Association, American Society of Public Administrators, Building Officials Conference of America, Steering Committee of the National League of Cities and Natural Resources Committee, American Society of Testing and Materials; Director, Regional Air Pollution Control Agency.

${ }^{1}$ Ch. 360,69 Stat. 322 (I955).

${ }^{2} 42$ U.S.C. $\$ 5$ 1 $857-1857 l\left(\mathrm{rg6}_{4}\right)$.

8I Stat. 485 . 
Financial aid

Continuing grant support to state and local agencies. Financial aid for interstate air quality planning activities. Awarding of grants to states to assist them in developing programs for inspection of motor vehicle pollution control systems.

Expansion of the federal government's research and development activities. Studies

Comprehensive economic studies of the cost of controlling air pollution.

An investigation of manpower and training needs in the air pollution field.

A study of the feasibility of controlling pollution from jet and conventional aircraft.

Continued efforts to control pollution at federal installations.

Control of motor
vehicle emissions $\left\{\begin{array}{l}\text { Continuation of federal standard-setting to control motor } \\ \text { vehicle pollution. } \\ \text { Registration of fuel additives. }\end{array}\right.$

Creation of a fifteen-member Presidential Air Quality Advisory Board.

Authority for
federal action $\left\{\begin{array}{l}\text { Retention of authority for federal action to abate inter- } \\ \text { state air pollution problems, and, on request from states, } \\ \text { intrastate problems. } \\ \begin{array}{l}\text { Action by the Secretary of the Department of Health, } \\ \text { Education, and Welfare to obtain court orders to curtail } \\ \text { pollution during emergencies. }\end{array}\end{array}\right.$

Establishment of advisory groups to assist the Department of Health, Education, and Welfare.

These provisions of the Air Quality Act of 1967 represent a practical, meaningful approach to many important aspects of the air pollution problem. However, the Act also provides for:

(x) A study of the need for and effect of national emission standards for stationary sources of air pollution.

(2) Definition of broad atmospheric areas of the nation and designation of specific air quality control regions by the Department of Health, Education, and Welfare.

(3) Development and publishing of air pollution criteria indicating the extent to which air pollution is harmful to health and damaging to property and detailed 
information on the cost and effectiveness of techniques for preventing and controlling air pollution by the Department of Health, Education, and Welfare.

(4) Development of air quality standards and plans for implementation of the standards by the states, as soon as air quality criteria and data on control technology are made available for a pollutant or class of pollutants. They will have ninety days to submit a letter indicating that they intend to set standards, 180 days to set the standards, and I8o days to develop plans for implementing them.

(5) Development and application of air quality standards on a regional basis. Wherever an air quality control region includes parts of two or more states, each state will be expected to develop standards for its portion of the region.

(6) Adoption of air quality standards and plans for implementation of the standards in an air quality control region, if the Secretary of Health, Education, and Welfare finds that these standards and plans are consistent with the provisions of the Air Quality Act. If a state fails to establish standards, or if the Secretary finds that the standards are not consistent with the act, he can initiate action to insure that appropriate standards are set. States may request a hearing on any standards developed by the Secretary; the hearing board's decision will be binding.

(7) Primary responsibility for application of the air quality standards being assumed by the states. If a state's efforts prove inadequate, the Secretary is empowered to initiate abatement action.

Deficiencies inherent in these seven provisions will permit pollution to be poured into the air we breathe for some time to come. A stronger, more immediate attack could have been-and should have been-launched against industrial sources of air pollution.

The Air Quality Act of Ig67 is deficient because it puts priority on the adoption of ambient air standards, and only provides for a study of the necessity for national emission standards for stationary sources of pollution. The Act should call for an immediate and direct frontal attack on the air pollution problem by demanding a reduction of industrial emissions at the source as soon as possible. National industrial emission standards should precede ambient air standards as a logical and necessary prerequisite to their attainment. The Act does not recognize the urgency of the problem stemming from stationary sources of pollution. It is possible for several time-consuming preliminary negotiations to take place before the Justice Department goes into federal court to seek to abate interstate air pollution. In many instances, HEW's inclination to act stands in place of deadlines. In other instances, HEW is prevented from taking action until an excessive amount of time has elapsed. The act attempts to force states to assume greater responsibility in air 
pollution abatement under threat of federal intervention. In addition, Congress has placed responsibility and the political power to develop and control regional programs in the hands of state governments. This responsibility has been delegated to the states in spite of the fact that, in the field of air pollution control, the state government has been, in most instances, the weak link in the federal-state-local government partnership.

The Air Quality Act of rg67 does not give proper priority to the establishment and enforcement of national industrial emission standards, nor does it properly recognize and support the activities of local air pollution control agencies which have been, to date, the best equipped and most effective in abating air pollution.

\section{Ambient Atr Standards Versus Emission Standards}

Public Law 159 enacted by the Congress in 1955 placed primary responsibility upon states and local governments for the prevention and control of air pollution at its source. This law recognized that air pollution must be controlled at the source-air pollution expelled into our atmosphere cannot be removed by a giant filter or other device. Enforcement of industrial emission standards limits air pollution at the source. Senate Bill 780 , as proposed, provided for such emission standards. Unfortunately, however, Congress disregarded all plans for national industrial emission standards after lengthy public hearings in which representatives of industry loudly decried the adoption of emission standards. As a result, a much weaker approach was adopted, and ambient air standards in designated air sheds were substituted for the proposed emission standards.

Why does substitution of ambient air standards for national industrial emission standards seriously weaken the effectiveness of the Air Quality Act?

Ambient air standards serve one primary purpose-they define the extent or limit of an air pollution problem. They do not tell who the polluters are, or provide guidelines for reducing pollution levels. An ambient air standard says in effect that a given pollutant should not exceed a predetermined level in the atmosphere because of aesthetic, economic, or health effects. Emission standards, on the other hand, limit the permissible discharge from sources of pollution. Emission of known pollutants in excess of specified levels is a violation subject to enforcement action. The enforcement of emission controls constitutes a direct attack on the problem.

Dr. John T. Middleton, Director of the National Center for Air Pollution Control, in hearings before Senator Muskie's Subcommittee on Air and Water Pollution on Senate Bill 780 , stated: ${ }^{4}$

'Hearings on Air Pollution-1967 (Air Quality Act) Before the Subcomm. on Air and Water Pollution of the Senate Comm. on Public Works, goth Cong., Ist Sess., pt. 3, at 1155-56 (1967). 
But no matter how stringent they may be, air quality standards are not, in themselves, a means of dealing with the sources of air pollution. There is no practical and equitable way of achieving an air quality standard in a given geographic area unless emission standards are established for the sources of pollution located in the area. An emission standard is, of course, a legally enforceable limitation on the amount of pollution that a single source or a category of sources can discharge into the atmosphere.

There is, however, another purpose for which emission standards can and should be established, for the fact is that individual sources of air pollution may produce injury to human health and damage to property independently of their effects on overall community air quality. Pollutant emissions from an individual source inevitably contribute to ground-level concentrations of pollution--either in the immediate vicinity of the source or even at substantial distances. It is to prevent such direct and needless hazards to public health and welfare that Federal emission standards would be established under the proposed Air Quality Act of I967.

...

This approach represents a logical and reasonable way of achieving emission control at many of the most important sources of air pollution in all parts of the country-sources which everyone agrees must be controlled.

Dr. Ivan L. Bennett, Jr., Deputy Director, Office of Science and Technology, Executive Office of the President, emphasized the need for prompt adoption of emission standards during the subcommittee hearings: ${ }^{5}$

Effective techniques for the reduction of air pollution from industrial sources of several types are known. Indeed, the Department of Health, Education, and Welfare has published several technical manuals on this subject. These technologies, however, have been incompletely utilized and have not come into general use. This unsatisfactory but understandable state of affairs is attributable mainly to the lack of firm guidelines and uniform standards.

The establishment and enforcement of uniform standards will undoubtedly ameliorate this situation. ...

Many of the chemicals that polluse our air are known to be highly toxic, even lethal when inhaled in large amounts over a short period of time-sulfur oxides and carbon monoxide are familiar examples. However, what the long-term effect of exposure to low concentrations of these substances, 24 hours a day, 7 days a week, for years on end will be is not known.

Furthermore, it will not be known with the scientific exactness that we would hope eventually to achieve until we have had opportunities to make the long-term observations, under appropriate conditions, that will give the definitive answer. And by the time that answer is available, the critical decade that lies ahead will have passed long since.

The question, then, is this: How much do we have to know before we begin to act?

\footnotetext{
Id., pt. 2, at 791-93.
} 
Without denying at all the urgent need for increased research to sharpen our knowledge and understanding of the physical effects of pollutants, I submit that we cannot wait until we have absolute and elegant proof before initiating action programs.

I am a biomedical scientist. It is time that we need to broaden the base of our understanding of the effects of air pollution. It is true that we are knowledgelimited in many areas, but these facts need not delay the initiation of action based on what we already know.

State and local air pollution control agencies should not be made responsible for enactment of industrial emission standards; basic emission standards should be nationwide. Industries in widely separated regions of the country are in direct competition with one another. To impose unequal restrictions on members of the same industry located in different regions would harm the more restricted firm and its community. This problem can only be avoided by well-defined national emission standards. A program which merely encourages state and local governments to adopt standards without setting any objective criteria which the standards must meet will be ineffective. Fear of economic injury to the community would of necessity keep state and local governments from setting suitably stringent emission standards.

John W. Gardner, then Secretary of the Department of Health, Education, and Welfare, testified before the Muskie Subcommittee on the need for national emission standards: $:^{6}$

The Clean Air Act and its amendments have been extremely useful. The proposed Air Quality Act of 1967 will enable us to take the additional steps that are needed.

First, emission control levels must be established for those industries which are major contributors to community air pollution problems in many parts of the country.

Currently, the responsibility for setting such levels is assigned almost entirely to State and local governments. But experience has proven that most States and cities will not take the initiative in requiring control measures beyond those required in other places; nor will industries support local or State control action which may place them at a competitive disadvantage.

By setting emission control levels that apply to all communities and all competitors in a given industry, we move toward pollution control in a manner that is fair to everyone, to all industries and to all communities.

The proposed Air Quality Act of 1967 would authorize the establishment of emission control levels for those industries which are nationally significant sources of air pollution. Following publication of the levels, each State would have an opportunity to adopt equivalent or more stringent levels. Federal action to enforce the standards would be authorized only in those States which fail to adopt adequate standards of their own. Establishment of such nationwide emission control levels will undoubtedly provide an attractive economic incentive to the development of

\footnotetext{
'Id. at 762 .
} 
control technology, and will result in better, cheaper, and most important, widely applicable ways of reducing pollution from specific sources.

Concerning national emission standards, Dr. Middleton testified: ${ }^{7}$

One of the major provisions of the proposed new legislation concerns the development of emission standards for the control of major industrial sources of air pollution. The responsibility for developing such standards is currently assigned to State and local governments, but for many reasons it is a responsibility that many of them cannot realistically be expected to meet in full measure.

Perhaps the most important of the factors that tend to discourage standard setting at the State and local levels is that such action seems inevitable to bring one major function of State and local governments-the protection of public health and welfare-into direct conflict with another-that of insuring economic growth. No matter how often we remind ourselves that effective control of air pollution is not incompatible with economic progress, the history of air pollution control efforts in this country provides abundant evidence that State and local officials are unable to take decisive action to adopt and enforce effective standards for the control of sources unless the problems have become so obvious, so severe and obnoxious as a nuisance that they cannot be tolerated. In most of our communities, as I have already emphasized, the air pollution problem today is not that flagrant, but I, for one, cannot accept the idea that we must allow it to become so.

Even if we were to make what I consider to be the unrealistic assumption that State and local governments could be expected to adopt emission standards as soon as they had access to the necessary technical information, the results would still be unacceptable. Inevitably, some State and local agencies would adopt fairly stringent standards, while others would take no action at all. Industries in one community might be free to pollute the air even though applicable control technology existed, while their competitors in a neighboring community might be required to invest in the most effective control equipment available. There would be no justice in such a situation, either for the people who must breathe the polluted air in the first community or for the industry which must control its pollutants in the second community.

Federal emission standards, as proposed in the new legislation, offers an approach that is inherently equitable to both industry and the public. This will mean the setting of standards for all those industries which are responsible for significant air pollution problems, wherever they happen to be located. There will necessarily be separate standards for individual types of pollutants, but in each instance they would be applied industrywide.

Some pollutants have been shown to travel great distances. An emission which does not present a problem in its particular region, because there is not a great concentration of other polluting sources, may be carried to another region where, when mixed with other pollutants in the air, it will create a problem. General control regulations will necessarily vary in the different air regions; but basic national industrial emission standards should be the same to prevent the possibility of emissions from low concentration areas contributing to the problems in areas of high pollution concentration.

\footnotetext{
'Id., pt. 3, at Ir53.
} 
National emission standards would provide incentives to develop devices to control specific types of pollution. Also, the biggest polluters would be controlled first, thus giving results immediately notable, and making this application of ambient air standards more acceptable to the populace when better procedures to establish and enforce ambient air standards have been devised.

In response to questioning following his testimony, Secretary Gardner discussed the role of emission standard setting in advancing the "state-of-the-art" of control technology: ${ }^{8}$

Senator Randolph. ... One of the problems, Mr. Secretary, with which the Congress of necessity will have to cope is the question of the degree of technological advance in this field. Could you state for the record of the subcommittee whether in your opinion there will be the so-called hand-in-hand procedure or whether the Federal standards would precede the technological advance?

I think it is important that we know whether the so-called state of the art, to use an expression, will go hand-in-hand with the emission crtieria which properly should be set.

Secretary Gardner. Yes, sir. It is perfectly clear, and it has been stated in the President's message, that we must take into consideration economic and technological feasibility in setting the standards. It is equally clear to me that the state of the art has tended to meander along until some sort of regulation took it by the hand and gave it a good pull, so our effort will be to stimulate and go to the state of the art rather than wait for it.

There has been a long period of waiting for it and it hasn't worked very well. It seems to me that the problem we face here is that industries, which will face problems as a result of air pollution control measures, will face more severe problems if they fail to control air pollution, because they will be walking head on not into the Federal Government, but into the interests of the American people, and the concern of the American people, the visible, rising concern of the American people.

This has been quite a striking thing to all of us in the past couple of years. The concern of the public about air pollution, and the popularity of air pollution control measures, is something that industry must cope with. If we can stimulate more rapid development of the state of the art through setting the standards at a point which we really have to reach for them, so much the better.

At present, air pollution monitoring procedures are not sophisticated enough, nor has monitoring been extensive enough to permit establishment of meaningful ambient air quality standards. A method of placing air monitoring devices to ensure the validity of comparisons made between various cities has not been devised. Further, at the present time there are not sufficient personnel to man competently the number of monitoring devices that would be necessary for effective national ambient air standards, even if an adequate national air monitoring system was in existence.

Pollution concentrations vary greatly with changes in weather conditions, and

\footnotetext{
-Id., pt. 2, at $766-67$.
} 
it has not yet been determined what weather will be considered the mean on which air quality standards will be based and how air quality standards will be measured at times when weather conditions vary from this mean. For example, in Denver, for the month of December, six particulate sampling stations showed a percentage reduction of twenty-seven per cent of suspended particulates and thirty-six per cent of benzene soluble hydrocarbons for I966 over I965. Meteorological records show nineteen days with a surface inversion ${ }^{9}$ in December 1965 , and no inversions in December I966. The average mixing depth of the air for December I965 was 380 meters as contrasted with 1527 meters for December I966. Denver Air Pollution Control's figures show an average reduction of emissions from stationary sources of about twenty per cent of both types of pollutants during the same time period. When the weather is favorable, ambient air records will indicate a greater reduction in emissions than has actually been achieved. When the weather is unfavorable, the reverse will be true.

Finally, there are problems in applying ambient air standards. How do you enforce an ambient air standard? If levels of a pollutant exceed the ambient air standard established for that pollutant, who is the violator? In the absence of emission standards, how can enforcement be carried out? If an individual pollutant was directly and indisputably traceable to one plant or one industry in an area, there would be little problem. But there are hundreds of contributors of each type of pollutant in most areas. Who will determine which one is to be cut down first? Will the states establish priorities, or will we wait for volunteers from among the industrial polluters? It is obvious that somewhere along the line the federal government will have to determine which industries come first and set emission controls as they have already done for the motor vehicle. But the obvious is going to be studied, and precious time will be lost because of it.

Section 2II(a) of the Act requires the Secretary to submit to Congress a comprehensive report on the need for and effect of national emission standards for stationary sources no later than two years after the effective date of this section. Assuming that the Secretary does make a positive recommendation for the control of certain industries through the enforcement of national emission standards, it is almost a certainty that the same interests that lobbied so effectively to "buy time" to continue polluting the atmosphere, will again present a united front to emasculate the Secretary's recommendation, or at least to delay further the date when effective enforcement of such emission standards would require industry to take steps to clear the air. The failure to provide national industrial emission standards to be enforced within a reasonable time is a glaring weakness of the Air Quality Act of Ig67.

The Air Quality Act of Ig67 puts the cart before the horse and sets a time schedule for the establishment of ambient air standards that could delay the enact-

\footnotetext{
- A surface inversion is an unfavorable weather condition which permits a build-up of pollution.
} 
ment of reasonable emission standards for a lengthy period of time; it fails to take into account the technological and personnel deficiencies that exist today that will further delay the development of air and weather monitoring systems requisite to the establishment of meaningful ambient air standards; and it fails to recognize that until such monitoring systems are a functioning reality, the ambient air cannot be proven to be unacceptable. In the meantime, flagrant violators can continue to spew pollution into the air.

The schedules for definition of atmospheric areas and air quality control areas by the Secretary of HEW, and those for adoption, implementation, and enforcement of air quality standards by the states permit too much time to elapse.

Section $\operatorname{rof}(a)$ of the Act allows the Secretary one year to establish atmospheric areas of the nation based on climate, meteorology, and topography. (The nation has already been divided into eight such regions by the Secretary. ${ }^{\text {aa }}$ ) The Secretary is further charged with the responsibility within eighteen months after passage of the act, of setting air quality control regions. These regions will be defined to a great extent by the boundaries of metropolitan areas. The regions will be designated on the basis of meteorological, topographical, social, and political factors which suggest that a group of communities should be treated as a unit for the purpose of setting and implementing air quality standards. Dr. Middleton indicated at the Briefing Conference on Air and Water Pollution held in Washington, D.C., March 14-I5, I968, that two to four of the more important control regions will be designated during Summer 1968, about thirty to thirty-five by July 1,1969 , and the remainder of two hundred-estimated to be the total-sometime after the eighteen month limit imposed by the Air Quality Act.

Under section 107 (b) (r), the Secretary shall as soon as practicable develop and issue to the states such criteria of air quality as in his judgment may be requisite for the protection of the public health and welfare. Dr. Middleton indicated at the Briefing Conference that criteria and related control technique information for particulates and sulfur dioxide will probably be available during Summer 1968.

Only after atmospheric areas, air quality control regions, criteria, and related information on control techniques are published by HEW does the Act have a direct effect upon the states responsible for the air quality control regions that have been designated. Then, section I08(c) gives the governor of a state, after he receives the air quality criteria and the recommended control techniques from the Secretary, an additional ninety days to file a letter of intent to hold a public hearing to adopt, within an additional 180 days, ambient air standards as proposed. The state then has an additional I80 days to adopt a plan to implement, maintain, and enforce the air quality standards adopted. If the Secretary decides that the air quality criteria adopted by the state and the means proposed to achieve these ends within a reasonable time are consistent with the recommendations of the Secretary and

\footnotetext{
${ }^{82} 33$ Fed. Reg. 548 (Ig68).
} 
that the state has ample enforcement authority to achieve these ends, then such standards and plan are consistent with the purpose of the Act and shall be the air quality standards and plan applicable to the state. The opportunity for delay in taking any positive abatement action adds up to thirty-nine months if the Secretary and the governors take full advantage of the time allotted to them under these sections.

Subsections $108(c)(2)$ and $108(c)(3)$ provide for intervention by the federal government to implement adoption and enforcement of air quality standards either upon request of the governor of a state, or if the governor fails to act within the time limits prescribed. Obviously, the less prepared a state is to meet the deadline, the greater the probability of the governor's relying on federal action with the consequence of even further delay in positive abatement action.

If the state or states involved fail to take adequate or reasonable action to implement the plan and standards, the Secretary shall serve notice on all interested parties and this failure must be corrected within I80 days or the Attorney General will bring an action against the erring state or states in an interstate region. If the problem is intrastate, the Attorney General, at the request of the governor, may assist in bringing suit in a state court or in the appropriate federal district court. Again, depending upon the enforcement capabilities of the state or municipal control agencies involved, the recalcitrance of the industries affected, the judgment of the Department of Health, Education, and Welfare as to whether reasonable efforts to control pollution are being exerted, and the condition of the court docket, the possibility for prolonged delay before positive abatement action is taken is all too apparent.

In entering a judgment, the court shall give due consideration to the practicality and to the technological and economic feasibility of complying with the standards promulgated. Thus, it is entirely possible for the court to rule that little or no abatement action over a period of as much as five years constitutes reasonable action toward compliance because the standards of air quality sought were impossible to attain due to technological or economic problems. The variables and intangibles involved in attempting to set economically, technologically, and equitably attainable ambient air standards for a single air shed are probably beyond the present capabilities of the units of government that will be involved in many air basins; and they will be for some time to come.

Where does one start to implement controls to meet nebulous and possibly unattainable standards? Whom do you tell to cut down first? And, how do you establish the fact that an industry is responsible for the excess pollution in the air over and above that prescribed in the standards when the actual condition of the air is an unknown factor?

National industrial emission standards imposing control first on the known major industrial pollutors would present no such problem. Immediate progress to- 
ward acceptable ambient air would be possible. Air monitoring networks could bet set up over a period of time, and competent personnel trained to operate the stations and evaluate the data obtained. Then, by the time a region reached or approached the desired air quality level, the science of accurate evaluation of the ambient air would probably be developed to the point where significant ambient air standards could be set. Only through the elimination of pollution at the source will clean air be achieved. Air pollution control should begin with emission controls in all areas, and the science of air evaluation can be developed while abatement action is being taken.

\section{II}

The Roles of State and Local Air Pollution AgenciesCapabilities, AuthortTy, and Polittcs

The National Municipal Policy for the National League of Cities for 1968 states: $:^{10}$

All sources of air pollution-governmental, industrial, and private-must be controlled. For effective control, national industrial emission standards must be established to avoid increased pressure on industry to leave urban areas and to avoid local fears of economic injury that may result when strong pollution control standards are established in one community, but not in another.

To supplement the national emission standards, regional air quality commissions should be established to deal with the particular air pollution problems in different air sheds-local communities and States should join together and develop regional programs in order to cope with the air pollution problems common to communities sharing the same air resources. These interjurisdictional programs must have meaningful regulations, backed by effective programs of enforcement. Local and regional pollution control agencies should have primary responsibility for enforcement of regulations as they are most immediately affected by pollution.

Where an effective local or regional agency exists, individual, unrestricted authority for air pallution control enforcement should be vested in this agency.

Air pollution is a metropolitan problem. Any city or metropolitan area with a population of 50,000 or more has an air pollution problem. It is local government that has taken the lead in air pollution control, and it is local government that is geared to the kind of activity required to abate air pollution. The local government is the political entity closest to the urban dweller, most cognizant of his problems, and subject to political retaliation if a problem is not solved satisfactorily. Also, the local governments, especially those of the larger cities, have existing departments staffed with technical, administrative, and enforcement personnel to plan and enforce an effective attack on air pollution.

Despite local government's record of achievement in air pollution control, nowhere in the Air Quality Act of 1967 is there any recognition of existing local

\footnotetext{
${ }^{10}$ National Municipal Policy, adopted at the 44th annual Congress of Cities, July 29-Aug. 2, 1967, Boston, Mass., ch. 8, $\$ \$ 8.203,8.204,8.206$. ( Emphasis added.)
} 
or regional agencies. The series of steps that must be taken to meet the requirements of the Act are all to be taken by governors of states. This state-oriented approach represents a departure from past policy of the federal government, which formerly dealt directly with the local government in matters of local concern or for the solution of urban problems where the state is acknowledged to be less wellequipped than local agencies, or less inclined to act. Secretary Gardner testified that: $:^{11}$

We have been quite disappointed in the vigor with which the States have approached this problem, and there are complications in their approaching it which make it understandable, but it now appears clear that waiting for them to act is not going to get the job done.

Two questions are automatically raised in light of the federal government's reliance on state action: How well prepared are the states to enact air quality standards? More importantly, how well prepared are the states to enforce air quality standards?

By 1967 , forty-five states had some sort of air pollution legislation, but having legislation on record is no guarantee of enforcement. A state statute calling for enforcement in the abatement field is a waste of time if qualified personnel and adequate funding are lacking. Most of the states are starting from scratch to build up a staff. The staffing problem of the state agencies is further complicated by inadequate budgets. A recent survey conducted by State Government Administraton revealed some sad statistics as far as funding and personnel at the state level are concerned. "One of the major problems noted in many survey responses is recruitment of adequate staffs to implement air pollution control programs."12

A "Current Status Report on State and Local Air Pollution Control Programs," as of May I967, was presented to the Muskie Subcommittee by Dr. Middleton. ${ }^{13}$ It revealed the following:

When the Clean Air Act was passed in December I963, only seventeen states had an action program. As of May 1967 , thirty-three states had air pollution control programs.

With thirty-four states receiving grant support under the Clean Air Act, the average state expenditure per capita was $4.8 \%$. With I07 local agencies receiving grant support under the Clean Air Act, the average local agency expenditure per capita was $27.9 \%$.

Of the thirty-four states, twenty-three were spending less than $5 \notin$ per capita per year on air pollution control. The highest yearly per capita expenditure for air pollution control by a state was $\mathrm{I}_{5.3} \%$ (California).

Of the ro 7 local agencies, fifty-six spent between $5 \phi$ and $25 \phi$ per capita per year

\footnotetext{
${ }^{11}$ Hearings, supra note 4 , pt. 2, at 764 .

12 Air Pollution . . A Critical Problem, State Gov't AD., Nov. 1967, at 7 .

${ }^{13}$ Hearings, supra note 4 , pt. 3 , at I $160-1283$.
} 
on air pollution control; only six spent less than $5 \%$; twenty-seven spent between $25 \phi$ and $50 \%$; twelve spent between $50 \%$ and $75 \%$; and five spent over $75 \%$ per capita. The highest yearly per capita expenditure for air pollution control by a local agency was $\$ 1.04$.

The average per capita expenditure by a local agency was 5.8 times the average state expenditure.

An appendix to this article shows the budgets, personnel, and per capita expenditures of state and local agencies receiving federal grant funds under the Clean Air Act in 1967 . Of the thirty-two states that budgeted funds for air pollution control, only eight had operating budgets larger than the budget of the largest local agency located within that state. California and New York State had the largest budgets of the states- $-\$ 2,407,000$ and $\$ 2,371,280$ respectively. Despite their large budgets, however, the total for local expenditures in New York $(\$ 2,005,300)$ approached the budgeted state expenditures, and the total of local expenditures in California $(\$ 5,252,700)$ was more than twice the state budget.

The state of Colorado is a case in point. Colorado first passed an air pollution control statute in 1964 , but the first statute giving the State Health Department any enforcement powers became effective in July of 1966 . The City and County of Denver, under the enabling provisions of the 1964 state statute, passed an ordinance in September of 1964 , that was then and is today more restrictive and easier to enforce than the state statute. Prior to passage of the state statute and staffing by the Colorado Health Department of an air pollution control agency, Denver had a staff of twenty experienced members, including five professional engineers with many years of design and construction experience in the power plant, metallurgical, chemical, foundry, and other industries that are responsible for air pollution emissions.

The approach to staffing is important. All the large effective local or regional air pollution control agencies, of which Los Angeles, Chicago, and the Bay Area are the best known, have administrative, engineering, enforcement, technical services, and public information sections staffed with professional engineers, chemists, mechanical inspectors, laboratory technicians, and public relations personnel. Some of the states, and obviously they are the ones with sufficient funds, have set up air pollution control agencies as distinct entities within their State Health Departments with organizations similar in make-up to those of the effective local control agencies. Build-up of a competent staff is relatively expensive, however, and in the absence of adequate funding, there is a tendency to compromise. It is apparent that if less qualified personnel are used to staff an agency, that agency is weaker than a properly staffed organization.

Putting the state in an equal or dominant position in the field of air pollution 
control ignores the fact that air pollution is a problem of urban origin that states historically have not had to cope with. Local governments, on the other hand, have dealt with the problems of urbanization for some time now, and have departments already in existence that are staffed to operate effectively in the enforcement field. Most of the abatement of air pollution has been accomplished at the local level. It will be difficult for states to bridge the gap of years of experience in this field in order to become full-fledged partners with local and regional agencies.

State agencies have a definite role to perform in combatting air pollution. They should be adequately financed and staffed to support weak local programs and to handle abatement procedures that lie outside of local jurisdictions, and they should be given authority to take over a local enforcement program where the local agency refuses or is unable to provide effective enforcement for political or other considerations. But, where an effective local or regional agency exists, that agency should be given individual, unrestricted authority for air pollution control enforcement. The Air Quality Act, by the explicit wording of section I05 and by the interpretation of the Department of Health, Education, and Welfare, as indicated in the provisions which govern the awarding of federal grants for air pollution control programs, gives the state the dominant position-and some control over local and regional agencies regardless of their relative accomplishments to date or ability to accomplish the purposes for which this bill was enacted.

This has opened the door for political problems.

Department of Health, Education, and Welfare regulations on "Grants for Air Pollution Control Programs"14 contain several references that would imply that an agency would have a difficult time obtaining federal funds without the approval of the state. For example, section 56.4 (c) states:

No grant shall be made until the Surgeon General has consulted with the appropriate official as designated by the Governor or Governors of the State or States affected pursuant to section I04(b) of the Act.

Under section 56.2, HEW requires a workable program containing seven comprehensive requirements that must be met before an applicant is eligible to receive federal funds. Subsection $5^{6.21}$ (d) states:

The Surgeon General shall approve a Workable Program and any revision or amendment thereof if, in his judgment, such program is reasonably calculated to prevent and control air pollution within the jurisdiction of the applicant: Provided, That prior to approving any Workable Program, or any revision or amendment thereof, the Surgeon General shall consult with the appropriate official as designated by the Governor or Governors of the States affected pursuant to section 104(b) of the Act.

Which takes precedence-the opinion of the Department of HEW or of the governor's official representative-as to whether or not the local or regional agency

\footnotetext{
${ }^{14} 42$ C.P.R., ch. I, subch. D, pt. 56 (1968).
} 
has submitted a workable abatement program? The opportunity for political manipulations open to the governor and the state is obvious. And what if the political appointee of the governor is unqualified to judge the effectiveness or the potential of the local or regional agency submitting the application? The usual recourse will be to ask the opinion of the head of the state air pollution control agency whose qualifications may also be less than optimal. Yet, this individual can have vested in him the power to make a judgment that can seriously jeopardize the chances of a well-qualified local agency to get a federal grant.

The ultimate objective of any air pollution control program is to establish an air resources management program, not just an abatement program. Freeways, mass transit, solid waste disposal, location of industrial and residential areas all have an effect on air pollution. An air resources management program provides maximum utilization of existing air resources, and this requires complete coordination within the basin of all local planning, zoning, engineering, public works, and air pollution control programs. The expertise that has existed in these fields for years is concentrated in local agencies and not in the states. Planning for improvement of the urban environment has almost never been a function, or until recent years even a concern, of state government. Metropolitan planning, with the multiplicity of jurisdictions with their own axes to grind, is difficult enough to accomplish when only local governments are involved. To insert the state into this melange, with the authority to pass on the final, workable plan, puts just one more obstacle in the path of metropolitan cooperation.

Local jurisdictions have been able to achieve some degree of metropolitan cooperation acting through inter-regional planning commissions or councils of governments. The qualifications of the personnel in various planning, zoning, building, engineering and public works departments in a metropolitan area is usually very impressive. If these talents can be coordinated by a council of governments and a master urban plan for an air basin worked out, taking into consideration the effects of air pollution on the environment, then the air pollution problem can be conquered. If an effective abatement program does not lead into an effective air resources management program in time to ward off and reverse the overwhelming effects of urban sprawl on the environment, it will never solve the pollution problem. For this reason alone, it is extremely important that a state agency or political appointee not be given the power to throw more sand into the already poorly-meshed machinery set up to solve metropolitan problems.

In the Denver metropolitan area, the Inter County Regional Planning Commission (ICRPC) is responsible for coordinated planning. The Regional Air Pollution Control Agency is the technical advisory committee for air pollution control for the ICRPC, the council of governments for Denver. Five counties-Adams, Arapahoe, Boulder, Denver, and Jefferson counties-plus twenty-one major municipalities within the counties other than Denver, signed the Articles of Association. With 
the exception of Boulder County, which did not affliate until October 1966 , all counties and most of the municipalities contained therein have been participating members of ICRPC since its inception in I955. Although membership and cooperation of the political entities which represent ninety-eight per cent of the metropolitan population is voluntary, ICRPC has a lever to snap reluctant counties or cities into line. It must approve most applications for grant-in-aid funds before the Department of Health, Education, and Welfare or the Department of Housing and Urban Development will even consider them.

ICRPC is well-qualified to coordinate planning in the Denver Metro area. It has a competent, professional staff that is familiar with local urban problems and able to evaluate the benefits of proposed programs, not just to the local applicant, but to the metropolitan region as a whole. Each project is considered in its relationship to the entire area. The Commission has the staff abilities to coordinate and utilize the efforts of manpower in the various local planning, zoning, engineering, and public works departments and experts in the private sector who comprise the various technical committees on air pollution, solid waste disposal, conservation, transportation and freeway studies-disciplines which are essential to the operation of an air resources management program. Over the past ten years, an average of over 500 knowledgeable experts have continuously contributed their expertise on urban problems through the advisory committees. Some of this advice has been disregarded and some has been rendered obsolete by the rapidly changing urban complex before it could be utilized; but most of it has been put to productive use. In thirteen years of operation, ICRPC has logged an impressive record of accomplishments. The State of Colorado, which entered the planning field in 1966 , is not in a position to supplant the services of ICRPC at this time.

HEW does not demand that applicants for clean air grants clear their application through recognized councils of governments such as ICRPC. Logic and common sense dictate that, where an effective council of governments exists in a region, applicants for air pollution control grants should be required first to submit those applications to the local government coordinating body, in order to determine whether or not the program objectives can be integrated into a comprehensive air management program for the air basin. Instead, the Air Quality Act gives an appointee of the governor the authority to recommend or deny approval of a grant. Thus, in theory at least, the governor has the political prerogative to disregard the advice of a competent planning body and rely on the political judgment of his appointee. Since there is no mandate in the Act requiring the governors to utilize the services of metropolitan councils of governments or regional planning boards established pursuant to interstate compacts, it is obvious that a judgment decision by a governor based on incomplete knowledge or political considerations can nullify the effectiveness of local or regional air pollution control authorities. This act is so slanted 
toward state control that it can be a powerful political tool, if a governor should choose to take advantage of it.

\section{SUMMARY}

The Air Quality Act of 1967 is not the strong decisive instrument needed to bring about an immediate, significant reduction in air pollution levels. While the increased research and development activity, funding to local and state agencies, emission controls for motor vehicles, and knowledge-expanding projects provided for in the Act are commendable, the lack of emphasis on immediate utilization of existing technology to bring industrial sources of pollution under control severely weakens the Act.

Air pollution is a very serious problem which threatens the health and welfare of every inhabitant of our earth. The effects of air pollution are known to be harmful and widespread. The exact extent of the problem is not known, nor is technology developed fully enough now to control all sources of air pollution emissions. But, wherever technology is adequate, that technology should be applied as quickly as possible in order to effect reductions in pollution levels. The Act sponsors the delay of action programs while definitive data on the extent of the problem is accumulated.

The Air Quality Act of 1967 is deficient because it does not make full use of the tools available. Present technology should be forced into application by imposing emission controls on industry. Relative qualifications and records of achievement of local and state air pollution control agencies should have dictated delegation of responsibility for action programs. It is wishful thinking to expect to force states to enter the enforcement field and act to do a job as quickly or as well as local agencies that have been doing it for years merely by empowering the states to do it. The delegation of too much political power to the states could act as a deterrent rather than a stimulus to the accomplishment of the intended objectives of the Act. The Air Quality Act of Ig6y does not fully recognize the urgency of the air pollution problem. 


\section{APPENDIX}

Budgets and Personnel of State and Local Air Pollution Control Agencies Receiving Federal Grants under the Clean Air Act As of May ig67 ${ }^{15}$

\begin{tabular}{|c|c|c|c|c|c|c|c|}
\hline 蜜 & 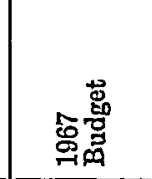 & 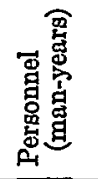 & 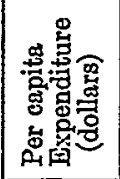 & 总总 & 营 & 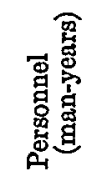 & 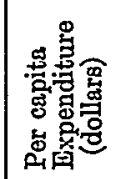 \\
\hline Alabams & $\$ 50,000$ & 6.5 & $\$ 0.015$ & $\begin{array}{l}\text { Huntsville } \\
\text { Jefferson Co. } \\
\text { Mobile Co. }\end{array}$ & $\begin{array}{r}14,700 \\
115,000 \\
29,400\end{array}$ & $\begin{array}{r}1.5 \\
10.5 \\
3.0\end{array}$ & $\begin{array}{r}\$ 0.204 \\
0.180 \\
0.094\end{array}$ \\
\hline Alaska & -0 & -0 & $-0-$ & & & & \\
\hline Arizona & -0 & -0 & & $\begin{array}{l}\text { Maricopa Co. } \\
\text { Pima Co. }\end{array}$ & $\begin{array}{r}135,600 \\
33,600\end{array}$ & $\begin{array}{r}14.0 \\
3.5\end{array}$ & $\begin{array}{l}0.205 \\
0.127\end{array}$ \\
\hline Arkansas & 58,020 & 7.0 & 0.032 & \multicolumn{3}{|c|}{ None as designated by state law } & \\
\hline California & $2,407,000$ & 98.0 & 0.153 & $\begin{array}{l}\text { Los Angeles Co. } \\
\text { San Bernardino Co. } \\
\text { Bay Area } \\
\text { Monterey Co. }\end{array}$ & $\begin{array}{r}3,758,200 \\
301,000 \\
1,126,000 \\
67,500\end{array}$ & $\begin{array}{r}305.0 \\
26.0 \\
76.0 \\
5.0\end{array}$ & $\begin{array}{l}0.622 \\
0.598 \\
0.348 \\
0.341\end{array}$ \\
\hline Colorado & 117,689 & 9.5 & 0.067 & $\begin{array}{l}\text { Denver City \& } \\
\text { County } \\
\text { Tri County } \\
\text { Jefferson Co. } \\
\text { Pueblo Co. }\end{array}$ & $\begin{array}{r}200,600 \\
75,000 \\
20,000 \\
35,500\end{array}$ & $\begin{array}{r}18.5 \\
7.5 \\
1.5 \\
3.5\end{array}$ & $\begin{array}{l}0.406 \\
0.321 \\
0.157 \\
0.301\end{array}$ \\
\hline Connecticut & 151,616 & 17.0 & 0.060 & $\begin{array}{l}\text { Bridgeport } \\
\text { Middletown } \\
\text { Fairfield } \\
\text { Stratford } \\
\text { New Haven } \\
\text { Stamford } \\
\text { Greenwich } \\
\text { Norwrolk } \\
\text { Milford }\end{array}$ & $\begin{array}{l}34,100 \\
21,700 \\
32,800 \\
31,400 \\
60,700 \\
41,600 \\
25,500 \\
36,600 \\
31,300\end{array}$ & $\begin{array}{l}4.0 \\
1.0 \\
1.0 \\
2.0 \\
5.0 \\
3.0 \\
1.5 \\
2.0 \\
1.0\end{array}$ & $\begin{array}{l}0.102 \\
0.658 \\
0.713 \\
0.70 \\
0.40 \\
0.452 \\
0.47 \\
0.546 \\
0.763\end{array}$ \\
\hline Delaware & -0 & -0 & & None & & & \\
\hline Florida & 175,000 & $15-20$ & & $\begin{array}{l}\text { Dade County } \\
\text { Palm Beach Co. } \\
\text { Mantee Co. } \\
\text { Hillsborough Co. }\end{array}$ & $\begin{array}{r}131,500 \\
54,800 \\
55,100 \\
52,000\end{array}$ & $\begin{array}{r}16.0 \\
\mathbf{5 . 5} \\
3.0 \\
3.5\end{array}$ & $\begin{array}{l}0.141 \\
0.24 \\
0.80 \\
0.13\end{array}$ \\
\hline Georgia & 48,735 & 8.0 & 0.012 & $\begin{array}{l}\text { Fulton Co. } \\
\text { Macon-Bibb Co. } \\
\text { Chatham Co. }\end{array}$ & $\begin{array}{l}30,000 \\
20,600 \\
18,600\end{array}$ & $\begin{array}{l}3.0 \\
2.5 \\
1.5\end{array}$ & $\begin{array}{l}0.054 \\
0.146 \\
0.10\end{array}$ \\
\hline Haพaii & 75,966 & 6.0 & 0.12 & None & & & \\
\hline Idaho & 26,982 & 2.5 & 0.04 & None & & & \\
\hline
\end{tabular}

15 The data presented here is based upon the Current Status Report on State and Local Air Pollution Control Programs, May 1967, in Hearings, supra note 4, pt. 3, at Ir60-1283. 
APPENDIX - Continued

\begin{tabular}{|c|c|c|c|c|c|c|c|}
\hline 要昜 & 兽兽 & 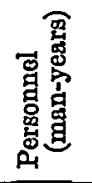 & 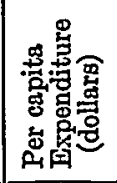 & 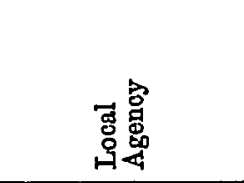 & 象莒 & 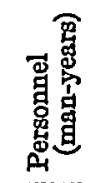 & 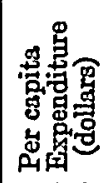 \\
\hline Tllinois & $\$ 156,466$ & 15.0 & $\$ 0.916$ & $\begin{array}{l}\text { Chicago } \\
\text { Cook Co. }\end{array}$ & $\begin{array}{r}\$ 1,162,700 \\
156,700\end{array}$ & $\begin{array}{r}140.0 \\
15.0\end{array}$ & $\begin{array}{r}\$ 0.187 \\
0.031\end{array}$ \\
\hline Indiana & 81,790 & 9.0 & $\$ 0.018$ & $\begin{array}{l}\text { E. Chicago } \\
\text { Gary } \\
\text { Evansville } \\
\text { Indianapolis } \\
\text { Michigan City } \\
\text { Hammond }\end{array}$ & $\begin{array}{r}40,300 \\
106,200 \\
25,200 \\
73,600 \\
7,400 \\
56,000\end{array}$ & $\begin{array}{l}3.5 \\
6.5 \\
2.0 \\
9.0 \\
0.5 \\
4.5\end{array}$ & $\begin{array}{l}0.707 \\
0.60 \\
0.179 \\
0.155 \\
0.206 \\
0.315\end{array}$ \\
\hline Iowa & -0 & -0 & -0 & Cedar Rapids & 26,800 & 3.5 & 0.20 \\
\hline Kansas & -0 & -0 & -0 & $\begin{array}{c}\text { Kansas City- } \\
\text { Wyandotte Co. }\end{array}$ & 98,900 & 7.0 & 0.635 \\
\hline Kentucky & 316,666 & 26.5 & 0.104 & None & & & \\
\hline Iouisians & 103,213 & 8.5 & 0.032 & None as designated & by State Lay & & \\
\hline Maine & -0 & -0 & -0 & None & & & \\
\hline Maryland & 95,000 & 9.0 & 0.031 & None & & & \\
\hline Massechusetts & 10,500 & 0.5 & 0.002 & $\begin{array}{l}\text { Worcester } \\
\text { Boston Metro } \\
\text { Springfield Metro }\end{array}$ & $\begin{array}{r}35,000 \\
134,300 \\
44,000\end{array}$ & $\begin{array}{r}4.0 \\
20.0 \\
5.0\end{array}$ & $\begin{array}{l}0.108 \\
0.067 \\
0.092\end{array}$ \\
\hline$\overline{\text { Michigan }}$ & 147,200 & 12.0 & 0.019 & $\begin{array}{l}\text { Muskegon Co. } \\
\text { Wayne Co. } \\
\text { Detroit }\end{array}$ & $\begin{array}{r}21,200 \\
193,400 \\
434,600 \\
\end{array}$ & $\begin{array}{r}1.5 \\
16.0 \\
40.0\end{array}$ & $\begin{array}{l}0.14 \\
0.194 \\
0.260 \\
\end{array}$ \\
\hline Minnesots & -0 & -0 & -0 & $\begin{array}{l}\text { St. Paul } \\
\text { Minneapolis }\end{array}$ & $\begin{array}{l}88,800 \\
67,100 \\
\end{array}$ & $\begin{array}{l}8.0 \\
6.5\end{array}$ & $\begin{array}{l}0.283 \\
0.130\end{array}$ \\
\hline Mississippi & -0 & -0 & -0 & None & & & \\
\hline Missouri & 108,108 & 7.0 & 0.025 & $\begin{array}{l}\text { St. Iouis Co. } \\
\text { St. Iouis City } \\
\text { Kansas City } \\
\text { Green Co.- } \\
\text { Springfield } \\
\end{array}$ & $\begin{array}{r}209,800 \\
252,300 \\
118,000 \\
46,900 \\
\end{array}$ & $\begin{array}{r}17.0 \\
7.5 \\
9.0 \\
3.0 \\
\end{array}$ & $\begin{array}{l}0.208 \\
0.336 \\
0.165 \\
0.494\end{array}$ \\
\hline Montana & 47,016 & 2.5 & 0.07 & Mizsoula & 23,700 & 3.0 & 0.539 \\
\hline Nebraska & -0 & -0 & -0 & None & & & \\
\hline Nevada & -0 & -0 & -0 & $\begin{array}{c}\text { Reno-Sparks- } \\
\text { Washoe }\end{array}$ & 47,000 & 5.0 & 0.56 \\
\hline
\end{tabular}


APPENDIX-Continued

\begin{tabular}{|c|c|c|c|c|c|c|c|}
\hline 里害 & 葛 & 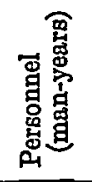 & 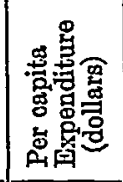 & 总总 & 蒂 & 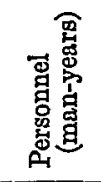 & 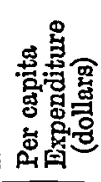 \\
\hline New Hampshire & $\$ 31,160$ & $2 . \theta$ & $\$ .0510$ & None & & & \\
\hline New Jersey & 808,081 & 69.0 & 0.133 & East Orange & $\$ 18,900$ & 1.0 & $\$ 0.245$ \\
\hline New Mexico & 13,162 & 2.5 & 0.014 & Albuquerque & 78,600 & 8.5 & 0.30 \\
\hline New York & $2,371,280$ & 50.0 & 0.14 & $\begin{array}{l}\text { Schnectady } \\
\text { Albany Co. } \\
\text { Mt. Vernon } \\
\text { Yonkers } \\
\text { Columbia Co. } \\
\text { Niagara Co. } \\
\text { N. Y. C. } \\
\text { Westehester Co. } \\
\text { Rensselaer Co. } \\
\text { New Rochelle } \\
\text { Erie Co. } \\
\text { Broome Co. } \\
\text { Dutchess Co. } \\
\text { Nassau Co. }\end{array}$ & $\begin{array}{r}6,300 \\
5,000 \\
8,200 \\
13,500 \\
6,000 \\
50,000 \\
1,509,900 \\
11,900 \\
7,500 \\
17,800 \\
108,300 \\
15,400 \\
8,100 \\
237,400\end{array}$ & $\begin{array}{r}0.5 \\
0.5 \\
0.5 \\
0.5 \\
1.0 \\
6.0 \\
120.0 \\
0.5 \\
1.0 \\
1.0 \\
8.0 \\
1.0 \\
1.5 \\
12.0\end{array}$ & $\begin{array}{l}0.041 \\
0.018 \\
0.108 \\
0.071 \\
0.128 \\
0.207 \\
0.194 \\
0.015 \\
0.053 \\
0.065 \\
0.102 \\
0.073 \\
0.046 \\
0.183\end{array}$ \\
\hline North Carolina & -0 & -0 & -0 & $\begin{array}{l}\text { Guilford Co. } \\
\text { Durham Co. } \\
\text { Buncombe Co. } \\
\text { Rowan Co. } \\
\text { New Hanover Co. } \\
\text { Gaston Co. } \\
\text { Mecklenburg Co. } \\
\text { Beaufort Co. } \\
\text { Cleveland Co. }\end{array}$ & $\begin{array}{l}25,600 \\
17,900 \\
17,700 \\
16,900 \\
16,700 \\
21,000 \\
45,600 \\
37,400 \\
23,200\end{array}$ & $\begin{array}{l}2.0 \\
2.0 \\
5.0 \\
1.0 \\
1.5 \\
1.5 \\
4.0 \\
2.5 \\
1.5\end{array}$ & $\begin{array}{l}0.104 \\
0.16 \\
0.136 \\
0.206 \\
0.235 \\
0.165 \\
0.168 \\
1.04 \\
0.35\end{array}$ \\
\hline North Dakota & -0 & 1.5 & -0 & None & & & \\
\hline Obio & 128,000 & 8.0 & 0.013 & $\begin{array}{l}\text { Lorain } \\
\text { Akron-Barberton } \\
\text { Toledo } \\
\text { Cleveland } \\
\text { Canton } \\
\text { Steubenville } \\
\text { Portsmouth } \\
\end{array}$ & $\begin{array}{r}29,100 \\
130,500 \\
67,500 \\
276,700 \\
53,000 \\
29.000 \\
25,700 \\
\end{array}$ & $\begin{array}{r}3.0 \\
11.0 \\
6.0 \\
33.0 \\
4.5 \\
4.0 \\
2.0\end{array}$ & $\begin{array}{l}0.428 \\
0.254 \\
0.212 \\
0.316 \\
0.47 \\
0.906 \\
0.78\end{array}$ \\
\hline Oklahoma & 10,290 & 1.0 & 0.004 & $\begin{array}{l}\text { Okla. City } \\
\text { Tulsa City-Co. }\end{array}$ & $\begin{array}{l}13,600 \\
37,000 \\
\end{array}$ & $\begin{array}{l}2.0 \\
3.0 \\
\end{array}$ & $\begin{array}{l}0.031 \\
0.107 \\
\end{array}$ \\
\hline Oregon & 187,393 & 15.0 & 0.106 & $\begin{array}{l}\text { Portland } \\
\text { Lane Co. }\end{array}$ & $\begin{array}{l}49,500 \\
42,600\end{array}$ & $\begin{array}{r}15.5 \\
4.5\end{array}$ & $\begin{array}{l}0.06 \\
0.263\end{array}$ \\
\hline Pennsylvanis & 369,475 & 44.0 & 0.03 & $\begin{array}{l}\text { Macungie } \\
\text { Philadelphia } \\
\text { Allezheny Co. }\end{array}$ & $\begin{array}{r}800 \\
445,900 \\
423,000\end{array}$ & $\begin{array}{l}28.1 \\
39.0\end{array}$ & $\begin{array}{l}0.21 \\
0.223 \\
0.26\end{array}$ \\
\hline
\end{tabular}


APPENDIX-Continued

\begin{tabular}{|c|c|c|c|c|c|c|c|}
\hline 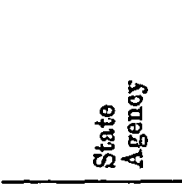 & 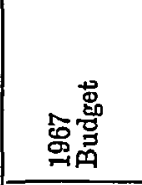 & 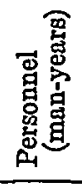 & 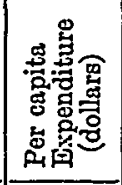 & 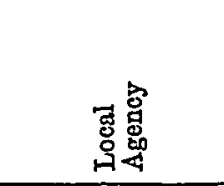 & 芯莒 & 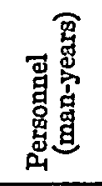 & 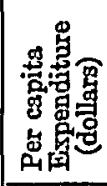 \\
\hline & & & & $\begin{array}{l}\text { York } \\
\text { Lehigh Valley }\end{array}$ & $\$ \begin{array}{l}20,000 \\
20,000\end{array}$ & $S \underset{2.0}{2.0}$ & $\begin{array}{l}\$ 0.084 \\
0.45\end{array}$ \\
\hline Rhode Island & \$ 10,471 & 2.0 & $\$ 0.012$ & None & & & \\
\hline So. Carolina & 70,606 & 5.0 & 0.03 & $\begin{array}{l}\text { Spartanburg } \\
\text { Charleston Co. }\end{array}$ & $\begin{array}{l}18,100 \\
34,000\end{array}$ & $\begin{array}{l}2.5 \\
3.0\end{array}$ & $\begin{array}{l}0.41 \\
0.157\end{array}$ \\
\hline Bo. Dakota & -0 & -0 & -0 & None & & & \\
\hline Tennessee & 12,660 & 3.0 & 0.004 & $\begin{array}{c}\text { Chattanooga } \\
\text { Nashville \& } \\
\text { Davidson Co. }\end{array}$ & $\begin{array}{l}42,300 \\
32,900\end{array}$ & $\begin{array}{l}4.0 \\
4.0\end{array}$ & $\begin{array}{l}0.325 \\
0.082\end{array}$ \\
\hline Texas & 107,611 & 10.0 & 0.011 & $\begin{array}{l}\text { Dallas } \\
\text { Lubbock Co. }\end{array}$ & $\begin{array}{l}67,700 \\
20,100\end{array}$ & $\begin{array}{l}7.0 \\
1.0\end{array}$ & $\begin{array}{l}0.171 \\
0.129\end{array}$ \\
\hline Utah & 39,268 & 3.0 & 0.044 & None & & & \\
\hline Vermont & $-0-$ & $-0-$ & -0 & None & & & \\
\hline Virginia & 25,000 & 2.0 & 0.002 & $\begin{array}{l}\text { Roanoke Co. } \\
\text { Hopewell } \\
\text { Richmond }\end{array}$ & $\begin{array}{l}16,100 \\
12,400 \\
43,400\end{array}$ & $\begin{array}{l}0.5 \\
1.0 \\
5.0\end{array}$ & $\begin{array}{l}0.284 \\
0.73 \\
0.106\end{array}$ \\
\hline Washington & 115,410 & 8.0 & 0.04 & $\begin{array}{l}\text { Seattle King Co. } \\
\text { Clark Co. }\end{array}$ & $\begin{array}{r}188,800 \\
22,200\end{array}$ & $\begin{array}{r}17.0 \\
1.5\end{array}$ & $\begin{array}{l}0.202 \\
0.239\end{array}$ \\
\hline West Virginia & 253,990 & 27.0 & 0.137 & Wheeling & 19,900 & 1.5 & 0.373 \\
\hline Wisconsin & -0 & -0 & -0 & Milmaukee & 226,600 & 20.0 & 0.219 \\
\hline Wyoming & 8,450 & -0 & 0.026 & None & & & \\
\hline
\end{tabular}

